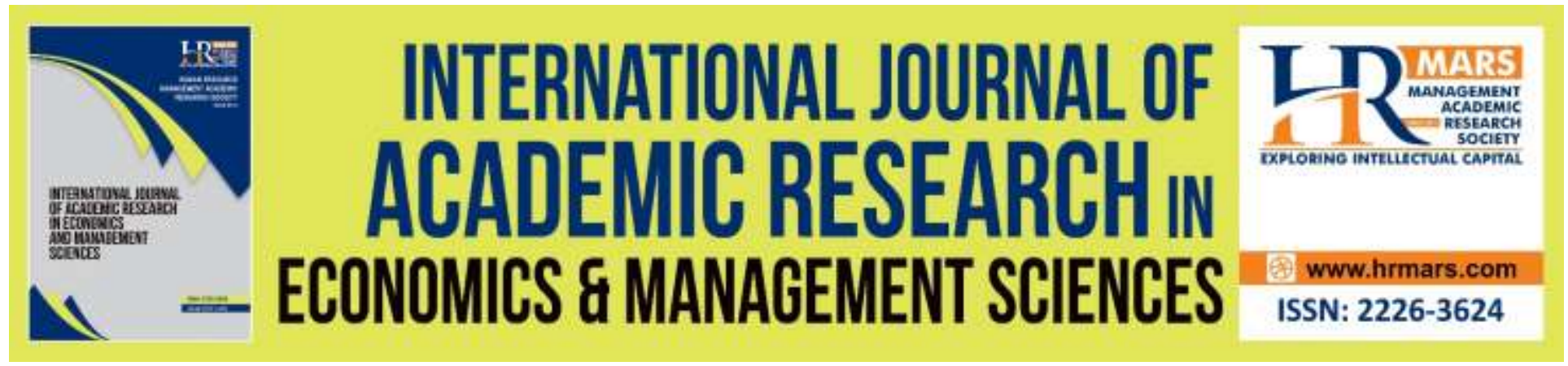

\title{
Disaggregated Energy Consumption and Industrial Output in Nigeria
}

Igbamiyemi Omosebi Ayeomoni, Saheed Aliu Aladejana, Kazeem Tunde Ajetunmobi \& Temitope Michael Asagunla

To Link this Article: http://dx.doi.org/10.6007/IJAREMS/v8-i4/6687

DOI:10.6007/IJAREMS/v8-i4/6687

Received: 13 November 2019, Revised: 29 November 2019, Accepted: 11 December 2019

Published Online: 27 December 2019

In-Text Citation: (Omosebi, Aladejana, Ajetunmobi, \& Asagunla, 2019)

To Cite this Article: Omosebi, A., Aladejana, S. A., Ajetunmobi, K. T., \& Asagunla, T. M. (2019). Disaggregated Energy Consumption and Industrial Output in Nigeria. International Journal of Academic Research in Economics and Management Sciences, 8(4), 15-26.

\section{Copyright: (c) 2019 The Author(s)}

Published by Human Resource Management Academic Research Society (www.hrmars.com)

This article is published under the Creative Commons Attribution (CC BY 4.0) license. Anyone may reproduce, distribute, translate and create derivative works of this article (for both commercial and non-commercial purposes), subject to full attribution to the original publication and authors. The full terms of this license may be seen at: http://creativecommons.org/licences/by/4.0/legalcode

Vol. 8, No. 4, 2019, Pg. 15 - 26

http://hrmars.com/index.php/pages/detail/IJAREMS

JOURNAL HOMEPAGE

Full Terms \& Conditions of access and use can be found at http://hrmars.com/index.php/pages/detail/publication-ethics 


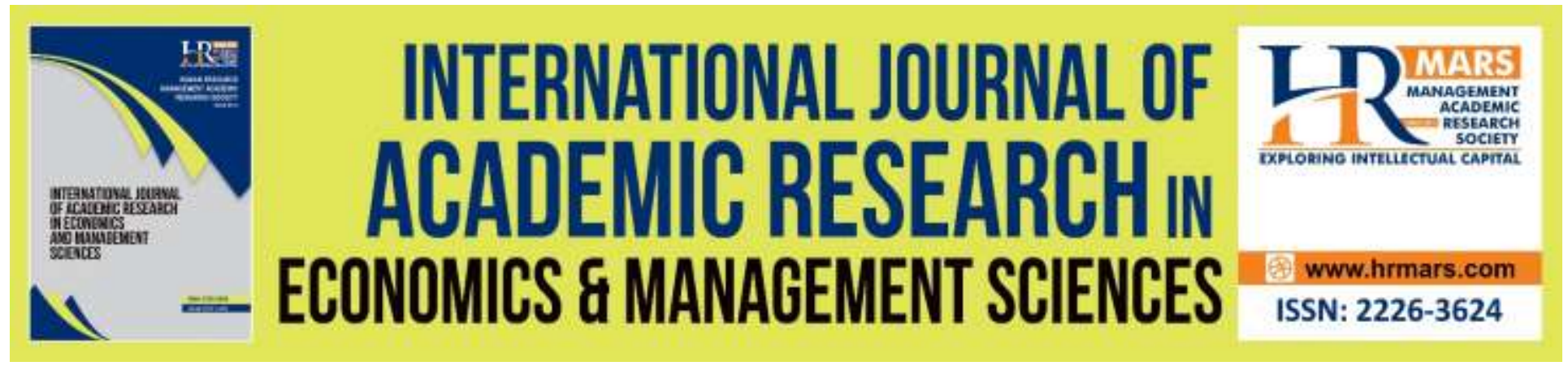

\title{
Disaggregated Energy Consumption and Industrial Output in Nigeria
}

\section{Igbamiyemi Omosebi Ayeomoni ${ }^{1}$, Saheed Aliu Aladejana ${ }^{2}$, Kazeem Tunde Ajetunmobi ${ }^{3}$, Temitope Michael Asagunla ${ }^{4}$}

${ }^{1}$ Postgraduate Student, Department of Economics, Adekunle Ajasin University, Akungba-Akoko, Ondo State, Nigeria, ${ }^{2}$ Department of Economics, Samuel Adegboyega University, Ogwa Edo State, Nigeria, ${ }^{3}$ Heritage Bank Plc, Ikare-Akoko, Ondo State, Nigeria, ${ }^{4}$ Postgraduate Student, Department of Economics, Federal University, Oye-Ekiti, Ekiti State, Nigeria.

1Email: ioayeomoni@gmail.com, 2aladejana26@gmail.com, ${ }^{3}$ kazeem.ajetunmob@hbng.com ${ }^{4}$ masagunla04@gmail.com

\begin{abstract}
Energy is fundamental to all human activities in every economy. Available findings on the relationship between disaggregated energy consumption and industrial output have been mixed and the previous studies failed to consider diesel and electricity which are important components of energy consumption. Hence, the study examined the nexus between disaggregated energy consumption and industrial output in Nigeria. The null hypothesis was that disaggregated energy consumption has no significant relationship with industrial output in Nigeria. The study applied the Fully Modified Ordinary Least Square method on data obtained from the Central Bank of Nigeria and International Energy Association Statistical Bulletin, 1986-2018, to examine the relationship between disaggregated energy consumption and industrial output in Nigeria. The findings showed a positive relationship between industrial output, premium motor spirit, diesel, coal and human capital. By implication therefore, the variables contributed significantly to increase industrial output within the study period. However, an inverse relationship existed between industrial output, consumption of gas, electricity, kerosene, and capital stock due to their inadequate, irregular and epileptic supply in Nigeria. The study concluded that industrial output is strongly influenced by premium motor spirit, diesel, electricity and gas consumption in Nigeria. The study, therefore, recommended that energy policies should be sector-specific, taking into cognizance the components of energy consumption that influence the industrial output in Nigeria.
\end{abstract}

Keywords: Disaggregated Energy Consumption, Industrial Output, Human Capital, Fully Modified Ordinary Least Square 
INTERNATIONAL JOURNAL OF ACADEMIC RESEARCH ECONOMICS AND MANAGEMENT SCIENCES Vol. 8, No. 4, 2019, E-ISSN: 2226-3624 @ 2019 HRMARS

\section{Introduction}

Energy is fundamental to all human activities in every economy. Osueke and Ezugwu (2011) estimated that about 1.6 billion people live without access to electricity and 2.4 billion are without modern energy sources for cooking and heating globally. For instance, in Nigeria, the industries depend on diesel, coal, gas, petrol, and electricity for their production. The magnitude and level of energy consumption by industries are determined by many factors-availability, affordability of energy consumption, sources of energy, capital structure, exchange rate, among others. Nigeria is an energy resource, rich economy, endowed with natural resources-coal, diesel, gas, crude oil, solar, wind, and biomass. However, over $70 \%$ of the Nigerians population does not have access to most of the energy especially electricity (International Energy Association, 2016). This implies that Nigeria as the most populous country in sub- Saharan Africa (nearly one quarter of sub-Saharan African 's population) had not been able to harness them for proper development of the country despite their huge National Energy resources. Nigeria's energy supply is at present almost entirely dependent on fossil fuels and firewood (conventional energy sources) which are depleting fast. The 2015 Distribution of Energy Consumption typified the current energy supply mix in the country which shows the total energy consumption, the share of natural gas was $5.22 \%$, electricity took $3.05 \%$, firewood had a lion share of $50.45 \%$ and petroleum product had $41.23 \%$ share. In terms of general composition, diesel, coal, electricity and oil are the main elements of total energy consumption in Nigeria. For example, coal shared about $78 \%, 82 \%$ and 42\% in 2000, 2005 and 2010 of the total primary energy consumed in Nigeria while premium motor spirit consumed $74 \%$ and $75 \%$ in 2014 and 2015 respectively. Again, $77 \%$ and $76 \%$ of gas were consumed in 2014 and 2015 in that order whereas electricity consumption stood at 31\% and 30\% in 2014 and 2015 (Central Bank of Nigeria, 2016).

However, evidence has shown that in Nigeria, the industrial sector is grossly underperforming over the years due to problems posed by the shortage of energy supply, infrastructural deficit and inability to access the energy supply (Bernard \& Adenuga, 2016). Despite the abundant reservoirs of energy resources in the country, the continued malfunctioning of various energy sources, also means that the growth and development of the industrial sector are greatly hindered in the economy. The inadequate, irregular and epileptic power supply, the high cost of fossil fuel, shortage in natural gas supply has imposed a severe cost on the industrial sector in Nigeria. Statistical evidence has shown that the share of the nation's industrial output to GDP was $93.61 \%$ in 1989 . The Industrial sector experienced a decrease from $11.4 \%$ in 1990 to $10 \%$ in 1991 . As compared with 1989, industrial contribution to GDP was not encouraging between 1984 and 1988. But from 1992 to 1998, the share of industrial contribution in total GDP experienced an increased from $109.6 \%$ to $117.3 \%$. But, in 1999 , the share of industry total GDP continued on a downward trend except in 2003 and 2005. The industrial output share GDP between the year 2006 and 2010 were $155.5 \%$ and $159 \%$ before it eventually increased from 169\% to 168.5\% in 2015 and 2016 (CBN, 2016). Thus, this shows that the industrial output sector contribution to GDP over the years has been on the decline. This dismal performance of the industrial output shows that all is not well with the sector. This may be attributed to several factors, chief of which is infrastructural decay, particularly, energy deficiency (Elijah \& Nsikak, 2013). 
The findings of previous studies on the relationship between energy and industrial output have varied considerably. Several factors might have led to this lack of consensus. For example, the different economic structures of the particular countries studied, especially those that are at different stages of development. It is also possible that the use of aggregate energy data has led to differences in outcomes. The use of aggregate energy data does not capture the degree or extent to which different countries depend on different energy resources (Yang, 2000). Some studies have focused solely on aggregate data and this may not be able to identify the impact of a specific type of energy on industrial output. Whereas, the use of disaggregated energy consumption-industrial output nexus allows us to identify the significant effect of different energy consumption on industrial output in Nigeria.

Although, many empirical analyses on the nexus between aggregate energy consumption and industrial output growth have been conducted in the literature (Erbaykal, 2008; Chebbi \& Boujelbene, 2008; Nwosa \& Akinbobola, 2012) while fewer studies examined disaggregated energy consumption and industrial output with mixed results in the literature. For instance, Ziramba (2009), Sari, Ewing and Soytas (2007) found a long-run relationship between the nexus. Qazi, Ahmed and Mudassar (2012) reported a positive relationship between the variables. But, Liew, Nathan and Wong (2012) found no relationship between them. In Nigeria, most of the studies (Ogunjobi, 2015; Nwajinka, Akekere \& Yousuo, 2013) considered electricity energy consumption and industrial output and the studies failed to consider other components of energy consumption (i.e. motor spirit, diesel, gas, kerosene, coal). Bernard and Adenuga (2016) examined disaggregated energy consumption (i.e. oil, gas, coal and carbon-dioxide emissions from industrial activities) and industrial output from 1980-2013). However, the study of Bernard and Adenuga (2016) failed to consider diesel, electricity, and kerosene which are important components of energy consumption. The likes of electricity and diesel are used by industries in other to improve output growth. The neglect of diesel, electricity and kerosene in the existing literature created an empirical gap for which this research work is designed to fill. Furthermore, the study also considered carbon-dioxide emission from industrial activities, which previous studies considered as the explanatory variable may be difficult to distinguish between the emission from industrial activities and industrial output and this may lead to spurious empirical results or multicollinearity in the study. Apart from being scanty in Nigeria, the empirical literature is weakened by not covering the recent period and such previous studies includeOgunleye and Ayeni (2012) for the period of 1970-2007; Nwajinka, Akekere and Yousuo (2013) for the period of 1970-2010; and Ogunjobi (2015) for the period of 1980-2012. Thus, this study seeks to examine the relationship between disaggregated energy consumption and industrial output in Nigeria using a fully modified ordinary least square (FMOLS) technique for the period 1986-2016. To guide this study, the following questions are-what is the nexus between disaggregated energy consumption and industrial output? What has been the effect(s) of disaggregated energy consumption on industrial output in Nigeria? The rest of this paper is organized as follows. Following this introduction, section two provides a literature review. Section three covers the method, section four deals with results while section five deals with discussion. Section six concludes the study.

This study has a significant role in literature. Firstly, test the relationship between disaggregated energy consumption and industrial output in Nigeria. Secondly, differing from previous studies, this study will use recent data and incorporate other components of energy 
INTERNATIONAL JOURNAL OF ACADEMIC RESEARCH ECONOMICS AND MANAGEMENT SCIENCES Vol. 8, No. 4, 2019, E-ISSN: 2226-3624 @ 2019 HRMARS

consumption as suggested in the literature. Thirdly, findings of the disaggregated energy consumption and industrial output would help the policymakers to know the appropriate policies to be employed, taking into the cognizance the components of energy consumption that influenced the industrial output in the country.

\section{Literature Review}

There is an extensive amount of academic literature dedicated to the relationship between aggregate energy consumption and industrial output growth (Chebbi \& Boujelbene, 2008; Liew, Nathan \& Wong 2012; Nwosa \& Akinbobola, 2012; Erbaykal, 2008). Nevertheless, there are few existing studies that have considered the relationship between disaggregated energy consumption and industrial output. For example, Bernard and Adenuga (2016) investigated the contribution of disaggregated energy consumption on the output of the industrial sector in Nigeria for the period of 1980-2013 using the error correction model. The result of the ECM result provides strong evidence in support of a convergent relationship between energy consumption and industrial output in Nigeria. While Ogunleye and Ayeni (2012) assessed the demand for energy at a disaggregated level for Nigeria over the period 1970-2007 using a multivariate co-integration approach and found no evidence of a long-run relationship between the energy sources in Nigeria. Also, in South Africa, Ziramba (2009) investigates the relationship between disaggregated energy consumption and industrial output between 19802005 using co-integration test and found that the long-run relationship existed between the variables.

More so, Sari, Ewing, and Soytas (2008) studied the relationship between disaggregated energy consumption and industrial production in the United States using Autoregressive Distributed Lag (ARDL) method. The result showed that the variance decomposition revealed that shocks to electricity and petroleum consumptions result mainly from disturbances in the production or supply of the products and not from domestic price and real income shocks. Whereas, Qazi, Ahmed and Mudassar (2012) examined the relationship between disaggregated energy consumption and industrial output in Pakistan for the period of 1972 to 2010, using Vector Error Correction Model (VECM) technique. The findings of the study revealed a positive relationship between disaggregated energy consumption and industrial output. The Granger Causality test showed that a bidirectional causality exists between industrial output and oil consumption, whereas uni-directional causation existed between electricity consumption and industrial output. Also, uni-directional causation was found between industrial output and coal consumption whereas no causation was found between gas consumption and industrial output.

Furthermore, some studies (Ugwoke, Dike \& Elekwa, 2016; Nwajinka, Akekere \& Yousuo, 2013; Ogunjobi, 2015) examined only electric energy consumption-industrial output nexus in Nigeria and their findings are inconclusive. For instance, Nwajinka, Akekere, and Yousuo (2013) explored the impact of electric energy supply on industrial sector productivity in Nigeria from 1970-2010 applying OLS. The finding shows that energy supply has no significant impact on industrial output in Nigeria. However, Ogunjobi (2015) found a positive relationship between industrial growth and electricity. However, Ugwoke, Dike and Elekwa (2016) found a negative and significant relationship between electricity consumption and industrial output in Nigeria.

Again, Liew, Nathan, and Wong (2012) sought the interdependence between energy consumption and sectoral output in Pakistan for the period 1980-2007 using co-integration and 
Granger causality tests. The results show no evidence of a long-run relationship between energy consumption and industrial output and also revealed that the bi-directional relationship existed between energy consumption and industrial output. In the same vein, Nwosa and Akinbobola (2012) explored the nexus between aggregate energy consumption and sectoral output in Nigeria between 1980-2010 using VAR. They found bi-directional causality between energy consumption and sectoral output. On the contrary, using VECM by Chebbi and Boujelbene (2008) found that the uni-directional relationship affirmed between energy consumption and sectoral output in Tunisia. While Erbaykal (2008) found a short and long-run relationship between electricity consumption and economic growth in Turkey for the period of 1970-2003 using ARDL.

In Nigeria, most of the studies (Ogunjobi, 2015; Nwajinka, Akekere \& Yousuo, 2013) focused on the nexus between electricity energy consumption and industrial output without considered other components of energy consumption (i.e. motor spirit, diesel, gas, kerosene, coal) which are considered to be germane in the field of economics. Only Bernard and Adenuga (2016) examined disaggregated energy consumption (i.e. oil, gas, coal and carbon-dioxide emissions from industrial activities) and industrial output from 1980-2013). The study of Bernard and Adenuga (2016) failed to consider electricity and diesel as part of energy consumption which is very essentials energy consumption in Nigeria. The neglect of electricity and diesel in the existing literature created an empirical gap for which this research work is designed to fill. Also, the study failed to use robust estimation technique. Apart from being few studies that considered disaggregated energy consumption and industrial output in Nigeria, the empirical literature is weakened by not covering the period of recent economic situations in the economy. Thus, this study examined the relationship between disaggregated energy consumption and industrial output in Nigeria using a fully modified ordinary least square (FMOLS) method for the period of 1986-2018.

\section{Method of Analysis}

This study examined disaggregated energy consumption - industrial output nexus in Nigeria using FMOLS. The disaggregated energy consumption components used for this study include premium motor spirit, gas, coal, kerosene, diesel, and electricity while the industrial output is measured by industrial output per annual. Premium motor spirit (PMS), diesel (AGO), kerosene (DPK) and electricity (ELECT) are sourced from the Central Bank of Nigeria statistical bulletin while data on gas (GAS) and coal (COAL) consumption are sourced from the International Energy Association (IEA) statistical bulletin for the period of 1986-2016. All variables are transformed into logarithms.

Furthermore, Conventional Neo-Classical theory is used as theoretical framework and this is written as: $Y=A K^{\alpha} L^{\beta}$

Where $Y, K, L$ and $A$ represent output, stock of capital, stock of labor and technological progress respectively. In support, Ghali and El-Sakka (2004) model are in agreement with conventional Neo-classical theory which states that capital, labor and energy as separate inputs, that is:

$Y_{t}=F\left(K_{t}, L_{t}, E_{t}\right)$

Where $\mathrm{Y}=$ industrial output, $\mathrm{K}=$ capital stock, $\mathrm{L}=$ labour, $\mathrm{E}=$ total energy consumption, and $\mathrm{t}$ $=$ time period. Taking the differential of equation (1) yields:

$d Y_{t}=Y_{k} d K_{t}+Y_{L} d L_{t}+Y_{E} d E_{t}$ 
INTERNATIONAL JOURNAL OF ACADEMIC RESEARCH ECONOMICS AND MANAGEMENT SCIENCES Vol. 8, No. 4, 2019, E-ISSN: 2226-3624 @ 2019 HRMARS

where: $d y$ is the partial derivative of $d Y$ with respect to its time. On dividing equation (2), through by $Y$ and re-arranging the resulting expression, we obtain the following growth equation:

$\mathrm{Y}=\mathrm{aK} \mathrm{t}+\mathrm{bL} \mathrm{t}+\mathrm{cE} \mathrm{t}$

Where a dot on the top of a variable implies that the variable is now in a growth rate form. The parameters $(a, b, c)$ are the elasticities of output with respect to capital, labor and energy respectively. The nexus between output, capital, labor and energy inputs described by the production function in equation (1) suggests that there may be long-run movements between the variables in the estimated model. Allowing for short-run dynamics in factor-input behavior, in the analysis would also suggest that past changes in capital, labor and energy could contain useful information for predicting future changes of output (Chafik \& Younces, 2012).

This study adopts Bernard and Adenuga's (2016) model with little modification. The model of Bernard and Adenuga state that industrial output is influenced by oil, gas, coal, carbondioxide emission from industrial activities in Nigeria and this model is specified in functional form as:

INDOUTPUT $=\mathrm{f}(\mathrm{OIL}, \mathrm{GAS}, \mathrm{COAL}, \mathrm{CO} 2, \mathrm{KAPT}, \mathrm{HUCT})$

The model of Bernard and Adenuga is modified such that electricity, diesel and kerosene were introduced into the model as part of essential components of energy consumption in Nigeria. Hence, the model is modified in order to suit the study and this is specified as follows: INDOUTPUT = (PMS, AGO, DPK, ELECT, GAS COAL, KAPT, HUCT)

Where INDOUTPUT, PMS, AGO, DPK, ELECT, GAS, COAL, KAPT and HUCT represent industrial output growth, premium motor spirit, diesel, kerosene, electricity, gas and coal consumption as key variables while capital stock and human capital are used as control variables in the model. Hence, the model is specified in econometric linear form as:

INDO $=\beta_{0}+\beta_{1} P M S+\beta_{2} A G O+\beta_{3} D P K+\beta_{4} E L E C T+\beta_{5} G A S+\beta_{6} C O A L+\beta_{7} K A P T+\beta_{8} H U C T+e$ (7)

Where: $\beta_{1}$ to $\beta 7=$ the parameters to be estimated and $e=$ the error term.

The theoretical expectations about the signs of the coefficients of the parameters are as follow: $\beta_{1}, \beta_{2}, \beta_{3}, \beta_{4}, \beta_{5}, \beta_{6}, \beta_{7}$ and $\beta_{8}>0$

To know the direction of analysis, the study commenced its empirical analysis by examining the stationarity status of the time series, which is then followed by the co-integration test. If the series is observed to be integrated of different orders, a linear combination of the series may be co-integrated (Nwachukwu \& Odigie, 2009). Furthermore, Engle and Granger (1987) pointed out that a linear combination of two or more non-stationary series may be stationary. If such a stationary linear combination exists, the non-stationary time series are said to be co-integrated. The stationary linear combination is called the cointegrating equation and may be interpreted as a long-run equilibrium relationship among the variables. To examine the existence of co-integration among the series, the Engel-Granger technique is utilized. The Engelgranger technique is observed to be most suitable for testing co-integration between two variables as against the Johansen co-integration test which is adopted when the model is a multivariate model given the possibility of having more than one co-integrating vector. Based on the evidence from the stationarity and co-integration test, the study applies a fully modified ordinary least (FMOLS) technique. The technique is used to estimate the model. In econometric techniques, FMOLS was originally used by Philip and Hansen (1990). The method applies the semi-parametric correction to eliminate the long-run correlation between the co-integration 
equation and the innovations unlike short-run estimation such as ARDL, VAR, and ECM, that mostly used by previous studies when the series was found stationary I (1) in the estimated model. The method provides optimal estimates of co-integration regression. The basic idea of the FMOLS technique is to account for the serial correlation and test for the endogeneity in the regressors that result from the existence of a co-integrating relationship in the model. In support, Chafik and Younces (2012) applied the FMOLS for estimating long-run parameters, the condition that there exists a co-integrating relation between a set of 1(1) variable is satisfied in the estimated model.

\section{Empirical Results}

Test of Unit Root and Co-Integration Results

The appropriate test has been developed by Augmented Dickey and Fuller (ADF) to consider whether a time-series has a unit root.

Table 1: Results of ADF Unit Root Test

\begin{tabular}{|l|l|l|l|}
\hline Variable level & ADF test & Critical value at 0.05 & Order of stationary test \\
\hline INDOUTPUT & $(6.819109)$ & $(2.967767)$ & $1(1)^{* *}$ \\
\hline PMS & $(4.996301)$ & $(2.957110)$ & $1(0)^{*}$ \\
\hline AGO & $(8.632696)$ & $(2.967767)$ & $1(1)^{* *}$ \\
\hline DPK & $(5.082101)$ & $(2.967767)$ & $1(1)^{* *}$ \\
\hline ELECT & $(5.824820)$ & $(2.967767)$ & $1(1)^{* *}$ \\
\hline GAS & $(5.927196)$ & $(2.971853)$ & $1(1)^{* *}$ \\
\hline COAL & $(5.788667)$ & $(2.967767)$ & $1(1)^{* *}$ \\
\hline KAPT & $(4.302993)$ & $(2.967767)$ & $1(1)^{* *}$ \\
\hline HUCT & $(4.834035)$ & $(2.971853)$ & $1(1)^{* *}$ \\
\hline
\end{tabular}

Source: Author's computation, 2018.

*denotes stationary at $5 \%$ level

** denotes stationary at $5 \% 1^{\text {st }}$ difference

$1(0)$ denotes at $5 \%$ level

I(1) denotes at $5 \% 1^{\text {st }}$ difference

Table 1 showed the empirical results of the ADF in the model. The empirical results showed that the series were stationary at first difference except for PMS which was found stationary at level and this implied that there existed short-run relationships between the data series in the study. Hence, the study concluded that the data series were integrated both at level and $1^{\text {st }}$ difference at a $5 \%$ significance level. 
INTERNATIONAL JOURNAL OF ACADEMIC RESEARCH ECONOMICS AND MANAGEMENT SCIENCES Vol. 8, No. 4, 2019, E-ISSN: 2226-3624 @ 2019 HRMARS

Table 2: Results of Co-integration Test

\begin{tabular}{|c|c|c|c|}
\hline Trace Statistic & 0.05 Critical Value & Hypothesized No of CE(S) & Prob** \\
\hline 438.0035 & 197.3709 & None * & 0.0000 \\
\hline 273.9675 & 159.5297 & At most $1 *$ & 0.0000 \\
\hline 187.3630 & 125.6154 & At most $2^{*}$ & 0.0000 \\
\hline 128.5175 & 95.75366 & At most $3^{*}$ & 0.0001 \\
\hline 86.23852 & 69.81889 & At most $4 *$ & 0.0014 \\
\hline 47.57470 & 47.85613 & At most 5 & 0.0531 \\
\hline 29.90261 & 29.79707 & At most $6 *$ & 0.0486 \\
\hline 13.84396 & 15.49471 & At most 7 & 0.0873 \\
\hline 0.736363 & 3.841466 & At most 8 & 0.3908 \\
\hline $\begin{array}{c}\text { Max-Eigen } \\
\text { Statistic }\end{array}$ & 0.05 Critical Value & Hypothesized No of CE(S) & Prob** \\
\hline 164.0360 & 58.43354 & None * & 0.0000 \\
\hline 86.60453 & 52.36261 & At most $1 *$ & 0.0000 \\
\hline 58.84548 & 46.23142 & At most $2 *$ & 0.0014 \\
\hline 42.27896 & 40.07757 & At most $3 *$ & 0.0278 \\
\hline 38.66382 & 33.87687 & At most $4^{*}$ & 0.0124 \\
\hline 17.67209 & 27.58434 & At most 5 & 0.5226 \\
\hline 16.05865 & 21.13162 & At most 6 & 0.2214 \\
\hline 13.10760 & 14.26460 & At most 7 & 0.0755 \\
\hline 0.736363 & 3.841466 & At most 8 & 0.3908 \\
\hline
\end{tabular}

Source: Author's computation, 2018.

Table 2 revealed that at least five series were co-integrated in the model at a $5 \%$ significance level. The findings confirmed that there existed a long-run equilibrium relationship between the variables in Nigeria.

Table 3: The Empirical Result of FMOLS

Dependent Variable: INDOUTPUT

\begin{tabular}{|l|l|l|l|l|}
\hline Variable & Coefficient & Std. Error & t-statistic & Prob. \\
\hline PMS & 11.41632 & 3.520136 & 3.243146 & $0.0039^{* * *}$ \\
\hline AGO & 6.081528 & 1.275797 & 4.766846 & $0.0001^{* * *}$ \\
\hline DPK & -0.824097 & 0.393094 & -2.096436 & 0.0483 \\
\hline ELECT & -3.896253 & 0.907681 & -4.292537 & $0.0003^{* * *}$ \\
\hline GAS & -2.064455 & 0.795214 & -2.596100 & $0.0169 * * *$ \\
\hline COAL & 0.092104 & 0.192914 & 0.477438 & 0.6380 \\
\hline KAPT & -1.261832 & 0.552874 & -2.282314 & 0.0330 \\
\hline HUCT & 1.984968 & 2.039911 & 0.973066 & 0.3416 \\
\hline R-squared & 0.636274 & & \\
\hline
\end{tabular}

Source: Researcher's Computation, 2018. 
Table 3 revealed that the effect of disaggregated energy consumption on industrial output in Nigeria. Premium motor spirit (PMS) and diesel (AGO) were found positive and statistically significant at 1 percent level. The findings showed that a unit percent increase in PMS and AGO led to about $1141.6 \%$ and $608.2 \%$ increase in industrial output in Nigeria. This result suggests a positive relationship existed between PMS, AGO energy consumption and industrial output in Nigeria. However, ceteris paribus, coal energy consumption (COAL) and human capital (HUCT) showed inverse signs with industrial output in the model, although they are not statistically significant. The results prove that a unit percent increase in COAL and HUCT bring about 9.2\% and 198.5\% increase in industrial output in Nigeria. By implication therefore, the variables (motor spirit premium, diesel, coal, and human capital) contributed significantly to increase industrial output within the study period.

However, inverse relationships existed between electricity (HELE), Gas (GAS) and industrial output in the estimated model and they are statistically significant. Furthermore, the coefficients of HELE and GAS are -3.896253 and -2.064455 and this implied that a unit percent increase in HELE and GAS bring about 389\% and 206\% percent decrease in industrial in the estimated model within the study period. Moreover, a negative but not significant relationship existed between kerosene (DPK), capital stock (KAPT) and industrial output in the model. This means that a unit percent increase in DPK and KAPT will lead to about $82 \%$ and $126 \%$ decrease in industrial output in Nigeria. The result showed that consumption of gas, electricity, kerosene and capital stock contributed significantly to decrease industrial output. The inverse relationship between industrial output, consumption of gas, electricity, and kerosene is due to their inadequate, irregular and epileptic supply in Nigeria. In addition, the adjusted $R$-square $\left(R^{2}\right)$ revealed the predictor power of a model and it is derived to be 0.636274 . This implied that disaggregated energy consumption explains about 64 percent systematic variation on industrial output for the period 1986-2016 in Nigeria.

\section{Discussions}

The stationary and co-integration tests applied confirmed that the variables were stationary and co-integrated in the study. Furthermore, the regression result for disaggregated energy consumption proxied by premium motor spirit, diesel, kerosene, electricity, gas, and coal consumption revealed a high level of significance with industrial output in Nigeria. One percent change in premium motor spirit and diesel bring about $1141 \%$ and $608 \%$ increase in industrial output; and, this is statistically significant at $5 \%$ and $1 \%$ significance level. By implication therefore, the variables contributed significantly to increase industrial output within the study period. Again, more access to disaggregated energy consumption by industrialists would improve industrial output in Nigeria. This result is in agreement with Bernard and Adenuga (2016), Ziramba (2009), Qazi, Ahmed and Mudassar (2012) who found positive relationship between disaggregated energy consumption and industrial output whereas the finding is contrary to Akerere and Yousuo (2013), Liew, Nathan and Wong (2012), who found no relationship between the variables. However, an inverse relationship existed between electricity, gas and industrial output in the estimated model and it is statistically significant and this may be due to inadequate, irregular and epileptic supply in Nigeria. The empirical results of the variables were contrary to the prior proposition in the estimated model but agreed with the study of Ugwoke, Dike and Elekwa (2016) who found a negative relationship between electricity consumption and industrial 
INTERNATIONAL JOURNAL OF ACADEMIC RESEARCH ECONOMICS AND MANAGEMENT SCIENCES Vol. 8, No. 4, 2019, E-ISSN: 2226-3624 @ 2019 HRMARS

output in Nigeria. But, previous studies (Ogunjobi, 2015; Benard and Adenuga, 2016; Ziramba, 2009) found a positive relationship between electricity consumption and industrial output.

\section{Conclusion}

This chapter sums up the research-findings while drawing out a conclusion from the summary of findings obtained through the estimated data for the period of study. The study assessed the relationship between disaggregated energy consumption and industrial output in Nigeria for the period 1986-2018 using a fully modified ordinary least (FMOLS) technique which provides useful insights for analyzing and forecasting the relationship between the variables in Nigeria. Utilizing the method, the following are the major findings of the study.

Firstly, the study found that the variables were stationary and co-integrated in the model. Secondly, the empirical results show that PMS, AGO, and GAS have a significant effect on industrial output in Nigeria. Thirdly, the adjusted R-squared shows that six-four percent (64\%) of the variations in industrial output can be explained by the predictor variables in the model. The study concluded that industrial output is influenced greatly by the consumption of premium motor spirit, diesel and gas in Nigeria within the period of study. Therefore, the study recommends that energy policies should be sector-specific, taking into cognizance the components of energy consumption that influence the industrial output in Nigeria.

\section{References}

Bernard, O. A., \& Adenuga, O. (2016). Is energy consumption relevant to industrial output in Nigeria? European Journal of Research in Social Sciences, 4 (4), 1-14.

Chafik, K., \& Younces, B. (2012). Is debt particularly related to the overlapping of the functions of C.E.O. and the President of the Board of Directors? Interdisciplinary Journal of Contemporary Research in Business, 3(10), 954-967.

Chebbi, H. E., \& Boujelbene, Y. (2008). Agriculture and non-agriculture outputs and energy consumption in Tunisia: Empirical evidences from Co-integration and Causality, $12^{\text {th }}$ congress of the European association of agriculture Economists - EAAE.

Elijah, U., \& Nsikak, J. (2013). Energy requirements and industrial growth in Nigeria: An ARDL approach. Proceedings of the NAEE/AEE Conference on Energy Resource Management in a Federal System, Challenges, Constraint, and Strategies. Nigeria, 74-96.

Engle, R., \& Granger, C. (1987). Co-integration and error correction: representation, estimation, and testing. Econometrica 55, 251-276.

Ewing, B. T., Sari, R., \& Soytas, U. (2007). Disaggregate energy consumption and industrial output in the United States. Energy Policy 35, 1274-1281.

Erbaykal, E. (2008). Disaggregate energy consumption and economic growth: Evidence from Turkey. International Research Journal of Finance and Economics, 20, 172-179.

Ghali, K. H., \& El-Sakka, M. I. T. (2004). Energy use and output growth in Canada: A multivariate cointegration analysis. Energy Economics 26, 225-238.

Liew, V. K., Nathan, T. M., \& Wong, W. (2012). Are Sectoral outputs in Pakistan led by energy consumption?' Economic Bulletin, 32 (3), 2326-2331.

Nwachukwu, T. E., \& Odigie, P. (2009). What drives privates saving in Nigeria. A Paper Presented at the Centre for the Study of African Economics (CSAE), Conference, University of Oxford. 
INTERNATIONAL JOURNAL OF ACADEMIC RESEARCH ECONOMICS AND MANAGEMENT SCIENCES Vol. 8, No. 4, 2019, E-ISSN: 2226-3624 @ 2019 HRMARS

Nwajinka, C. C., \& Akekere, J., \& Younces, P. O. J. (2013). National electric energy supply and industrial productivity in Nigeria from 1970-2010. Journal of Economics and Sustainable Development, 4(4), 122-129.

Nwosa, P. I., \& Akinbobola, T. O. (2012). Aggregate energy consumption and sectoral output in Nigeria. African Research Review (ARR), 6 (4), 206-215.

Ogunjobi, O. J. (2015). The effects of electricity consumption on industrial growth in Nigeria. Journal pf Economics and Sustainable Development, 6(13), 54-59.

Ogunleye, E. O., \& Ayeni, R. K. (2012). Energy demand in Nigeria: A disaggregate analysis. International Research Journal of Finance and Economics, 86, 52-62.

Osueke, C.O., \& Ezugwu, C.A.K. (2011). Study of Nigeria Energy Resources and Its Consumption. International Journal of Scientific \& Engineering Research, 2, (12), 1-8.

Pesaran, M. H., Shin, Y., \& Smith, R. J. (2001). Bounds testing approaches to the analysis of level relationships. Journal of Applied Econometrics 16, 289-326.

Phillips, P. C., \& Hansen, B. E. (1990). Statistical inference in instrumental variables regression with I (1) processes. Review of Economic Studies, 57, 97-125.

Qazi, A., Ahmed, K., \& Mudassar, M. (2012). Disaggregate energy consumption and industrial output in Pakistan: An empirical analysis. Discussion paper No. 2012 to 2029. Kiel Institute for the World Economy.

Sari, R., Ewing, B., \& Soytas, U. (2008). The relationship between disaggregated energy consumption and industrial production in the United State: An ARDL approach, 2001.1 2005.6. Energy Economics 30, 2302-2313.

Sari, R., \& Soytas, U. (2004). Disaggregate energy consumption, employment, and income in Turkey. Energy Economics 26, 335-344.

Ugwoke, T. I., Dike, C. K., \& Elekwa, P.O. (2016). Electricity consumption and industrial production in Nigeria. Journal of Policy and Development Studies, 10 (2), 8 -19.

Wolde-Rufael, Y. (2004). Disaggregated energy consumption and GDP, the experience of Shangai 1952-1999. Energy Economics 26, 69-75.

Yang, H. Y. (2000). A note on the causal relationship between energy and GDP in Taiwan. Energy Economics, 22(3), 309-317.

Ziramba, E. (2009). Disaggregated energy consumption and industrial production in South Africa 1980- 2005. Energy Policy, 37 (6), 2214-2220. A4 